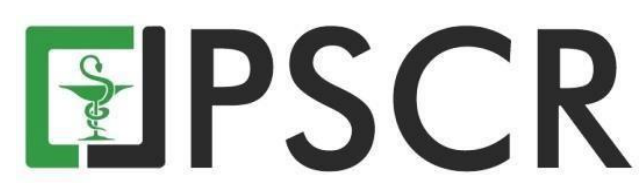

\title{
Activity Test of Durian Peels Essential Oil (Durio zibethinus) as an Antipediculosis Against Pediculus humanus capitis Linn. (Anoplura: Pediculidae)
}

\author{
Yuli Wahyu Tri Mulyani*, Siti Nurjanah, Samsuar dan Laila Susanti \\ Department of Pharmacy, Universitas Tulang Bawang, Jl. Gajah Mada No. 34, Kota Baru Bandar Lampung, \\ Lampung, Indonesia, 35128. \\ *email korespondensi: yuli.trimulyani@utb.ac.id \\ Received 29 March 2021, Accepted 11 November 2021, Published 15 November 2021
}

\begin{abstract}
Pediculosis is a disease caused by infestation of head lice (Pediculus humanus capitis) which is a blood-sucking obligate ectoparasite. The essential oil of durian fruit peel has active compounds that have the potential as vegetable pediculosides that can kill head lice. This study aimed to find the best concentration of essential oil from durian fruit peels that can kill head lice. The research design used with an essential oil concentration of $100 \%, 75 \%, 50 \%$, $25 \%$, distilled water as negative control and permethrin $1 \%$ as positive control, three repetitions and each concentration consisting of 10 flea tails. The parameters observed were the condition of lice morphologically based on the activity of limb movement, antenna movement and digestion, then the calculation of mortality was observed based on the time of the test. The results showed that the concentration of durian peel essential oil as an antipediculosis had a significant effect on the time of death of head lice, limb movement and digestion. The test result showed that the concentration is $100 \%$, has a death time of 12 minutes 32 seconds, $75 \%$ concentration was 16 minutes 28 seconds, 50\% concentration was 21 minutes 11 seconds, $25 \%$ concentration was 32 minutes 23 seconds, negative control was 61 minutes 15 seconds. The fastest time of death in positive control for chemical pediculosides was 10 minutes 15 seconds. The conclusion in this study was that essential oils the dominan one is 1,5naphthyridin-2-amine were proven to kill head lice and the best concentration was close to positive control, namely at a concentration of $100 \%$.
\end{abstract}

Keywords: durian fruit peel; essential oil; hexadecanoic acid; Pediculosis; Pediculus

\section{Introduction}

Pediculosis capitis is caused by infestation of head lice (Pediculus humanus capitis) which is an obligate ectoparasite that sucks blood on the human head (Irianto, 2013). Pediculosis is transmitted through direct contact with sufferers and indirect contact through clothes, combs, towels or sleeping together with sufferers. The incidence of pediculosis is influenced by age, sex, socio-economic and hygiene (Amelia et al., 2018). The prevalence of this disease is quite high, especially in pre-school children because at that age they are less able to maintain personal hygiene independently (Burgess, 2009).

Data on patients with pediculosis capitis in Indonesia have not been found, but research has been carried out in several areas. Pediculosis patients were recorded at Elementary School at Jatinangor was $51.92 \%$ and Sumedang was $55.3 \%$ (Karimah et al., 2016). Head lice in 
Indonesia are considered harmless, even though if they are not treated promptly, they will cause relapsing fever which is caused by an infection on the sufferer's scalp (Chandrasekar et al., 2015). The presence of head lice can also cause iron deficiency and anemia. In children infected with adult head lice, about 30 can lose blood of approximately $0.008 \mathrm{ml}$ per day (Fang et al., 2008).

Controlled of Pediculosis can be handled in two ways, namely mechanically and chemically. Mechanically it can be done by maintaining the cleanliness of the head, while chemically it can be done by using head lice killer drugs on the market (Coats et al., 1991). The use of chemical insecticides is believed to be able to eradicate disease vectors quickly but have a bad impact on human health and the environment if used excessively and continuously.

Based on the high negative impact of using chemical insecticides, an alternative is needed to eradicate head lice (Pediculus humanus capitis) using natural insecticides. One of the natural insecticides that can be used to eradicate head lice is durian peel essential oil. Durian (Durio zibethinus) is a type of fruit originating from Indonesia and its production is very abundant when the durian season arrives. Durian fruit is in great demand by the community, especially in Indonesia. According to research by the statistical agency, durian production in Indonesia from 2015-2019 reached 1,169,804 tons. During the durian season, environmental problems arise due to untapped durian peel waste. The increasing number of fans of durian fruit has resulted in even more durian peel production, often even durian peel is scattered on the roadside and the aroma becomes polluted. Research on durian skin that has currently been carried out includes antibacterial, antifungal and repellent activities against several insects (Nwaichi \& Osuoha, 2018). Research related to durian peel essential oil as an antipediculosis has not been widely done, most studies related to antipediculosis used other plant extracts such as papaya leaves and noni fruit.

Based on screening and identification phytochemical of the main components of the methanol extract of durian peels. Durian peels were positive for alkaloids, flavonoids, saponins, steroids, triterpenoids and tannins (Mulyani et al., 2019). On the basis of information obtained from literature studies on the use of durian peel waste as an alternative to natural medicine, in this study the researchers made essential oils from durian peel as an antipediculosis against head lice (Pediculus humanus capitis). The purpose of this study was to prove the antipediculosis activity and to find the best concentration of durian fruit peel essential oil which can kill head lice (Pediculus humanus capitis). 


\section{Material and Methods}

\subsection{Materials}

The test material to be used was ripe durian fruit peel. The test materials used were obtained from the durian sales center on Jalan Sultan Agung Kedaton Bandar Lampung. Preparation of Durian Peel; The durian fruit and seeds were separated from the peel, then the durian fruit peel was cleaned of impurities that stick to the durian peel using running water then the durian fruit peel was chopped coarsely then dried and air dried for about two days then to ensure that the simplicia was completely dry, the simplicial was put in oven at a temperature of $50^{\circ} \mathrm{C}$ until dry. Characterization test and standardization of simplicia; The dry simplicia, before the stage of simplicia extraction was carried out, it was characterized for moisture content, ash content, and acid insoluble ash content. This measurement was done to ensure that the simplicia used meets the drug raw material standards.

\subsection{Extraction and distillation}

Dried peel of durian fruit was mashed to form a powder and the peel of durian fruit which has been powdered were weighed for 500 grams. The water bath was filled with water and then the heating temperature is adjusted. After that, 500 grams of the powder of durian fruit peel was put into a three-neck extractor flask and $1000 \mathrm{ml}$ of $\mathrm{n}$-hexane solvent was added and then placed. The tip of the flask was directed at the condenser vertically and the top end of the condenser was closed so that no steam comes out, all the vapor would condense back into the solvent. The extractor was assembled by adding a condenser on the right side of the neck, a thermometer on the left side of the neck, and a stirring motor on the middle neck. Then the extraction process temperature at $25^{\circ} \mathrm{C}$ was set and the extraction time for 15 minutes simultaneously. After that, the heating device was turned off and the extractor flask was separated from the water bath. The mixture of ingredients and solvents was separated using a filter to obtain the extract and raffinate (dregs). The results of the separated dregs were squeezed using a porous cloth until there was no liquid remaining in the dregs.

Distillation process began by reinserting the solution that was separated from the pulp (extract) into the distillation flask. After that, a distillation device was assembled by placing a condenser on the neck of the flask and the distillation process was conducted at a temperature of $75^{\circ} \mathrm{C}$ get distillate (oil) and residue (solvent). The results of the distillate were put in the distillation flask and then put into the sample bottle then the sample bottle was closed and stored in a refrigerator or desiccator.

\subsection{Chemical analysis by GC-MS}

Gas Chromatography Mass Spectrophotometry (GCMS) was applied to screen essential 
oil components. It is a chemical tool that is widely used in sample analysis. The samples analyzed was separated first with a GC (Gas Chromatography) tool, then identified by means of an MS (Mass Spectrometry) tool. GC and MS were the simultaneous combination of forces to separate and identify the components of the mixture in a sample. GC-MS was used for qualitative identification and quantitative measurement of the individual components in volatile complex mixtures such as essential oils. The results of the essential oil screening would be used as the basis for chemical compounds having the potential to be antipediculosis. A sample of durian peel essential oil was injected into a GCMS which has a J\&W Scientific, HP-5MS capillary column with a length of $30 \mathrm{~mm}$, a diameter of $0.25 \mathrm{~mm}$ and a thickness of $0.25 \mathrm{~m}$. Helium carrier gas at a flow rate of $1 \mathrm{ml} / \mathrm{min}$ (constant) with a split ratio of 1:10. The programmed oven temperature was $50^{\circ} \mathrm{C}$ and kept isothermal for 5 minutes, the rate of increase was $10^{\circ} \mathrm{C} / \mathrm{min}$ and the temperature was increased to $280^{\circ} \mathrm{C}$ for 15 minutes. The injector port temperature is $290^{\circ} \mathrm{C}$ and the mass spectrometer interface is $230^{\circ} \mathrm{C}$ Identification of phytochemical compounds using the Willey database version 7.0 by comparing the mass spectrum pattern and the fragmentation pattern of reference compounds stored in the Willey library (Orole, 2016).

\subsection{Antipediculosis test}

The population of lice in this study were adult lice found in elementary school children aged 6-12 years. The technique used in sampling was purposive sampling according to the criteria required in this study, namely 1) Head lice have not been under any kind of oral or topical treatment in the last 4 weeks, 2) The lice taken were adult lice, 3) The lice are retrieved under optimal morphological conditions (complete limb) and 4) Lice were taken no more than 60 minutes from the respondent's head (Tohit et al., 2017).

The test for head lice mortality was carried out on sterile petri dishes covered by filter paper with concentrations of $100 \%, 75 \%, 50 \%$ and $25 \%$, repetitions were carried out 3 times, each concentration consisting of 90 head lices. As a positive control, a flea medication in the market with the active ingredient permethrin was given, negative control using aquadest. The essential oil of durian fruit peel was applied by dripping it on filter paper until it was evenly distributed throughout, then the lice were placed on it and dripped with durian peel essential oil. The data collected was the number of tick deaths by looking the movement of the ticks and the digestive activity of the lice after receiving treatment, to observe them under a microscope. The condition of lice was morphologically seen based on the activity of limb movement, spiracle, antenna, movement, and digestion can be grouped as follows: 1) Fleas move and walk actively, 2) Active movement of the legs and antennae as well, 3) Active digestion, 4) Minimal 
movement and visible activity decreased digestion and 5). Fleas that are said to be dead, if they are in condition number 3,4 , that is there is no movement.

\section{Results and Discussion}

\subsection{Durian peel simplicia characteristic test}

The simplicia characteristic test that has been carried out is a non-specific simplicia parameter test, the minimum test limit is three tests including simplicia water content, ash content and acid insoluble ash content (Table 1).

Table 1. The results of the durian peel dry simplicia (Durio zibethinus) characteristic test.

\begin{tabular}{ccc}
\hline Parameter & Result (\%) & Standard Requirement \\
\hline Water content & $6.8 \pm 0.72$ & $<10 \%$ \\
Ash content & $6.6 \pm 0.55$ & $<8.6 \%$ \\
Acid insoluble ash content & $2.0 \pm 0.19$ & $<2.9 \%$ \\
\hline
\end{tabular}

Determination of water content simplicia aimed to provide a minimum limit or range of the amount of water content in the material. Testing the water content using the gravimetric method, the durian peel moisture content obtained is $6.8 \%$ the water content has met the standard quality of simplicia that has been set, which is less than $10 \%$. Determination of ash content and acid insoluble ash content aims to provide an overview of the internal and external mineral content from the beginning to the formation of the extract. The ash content obtained is $6.6 \%$, the results obtained have met the specified quality standard of simplicia, namely $8.6 \%$. The insoluble ash content of durian peel simplicia acid has met the standard, namely the obtained results of $2 \%$ of the specified standard, which is not more than $2.9 \%$. Simplicia that has passed the test of simplicia characteristics that meet the standards that have been set proves that durian peel simplicia is a simplicia that has good internal and external water content and mineral content (Departemen Kesehatan RI, 2000).

\subsection{Head lice test results}

Research on durian peel essential oil on the death of human head lice can be said to be successful in killing head lice, although the time needed is still faster using head lice drugs on the market. The time difference between the $100 \%$ concentration of the essential oil of durian peel and synthetic flea medication is only 2 minutes at a concentration of $100 \%$. The ANOVA result data were then analyzed further using the Tukey test, presented in Figure 1.

Based on the results of Tukey's further test, the positive control had a shorter time than other treatments, but it was not significantly different from the $100 \%$ concentration of essential oil treatment but significantly different from the concentration of $75 \%, 50 \%, 25 \%$ and negative control. The time difference between positive control (drugs sold in the market) is only about 2 minutes with a concentration of $100 \%$ durian peel essential oil. Essential oils have biological 
activity against insects that are repellent, attractive, contact toxins, respiratory toxins, reduce appetite, inhibit egg laying, inhibit growth, and reduce fertility, including head lice (Irianto, 2013). Figure 1 describes the time of tick death with three repetitions in each treatment.

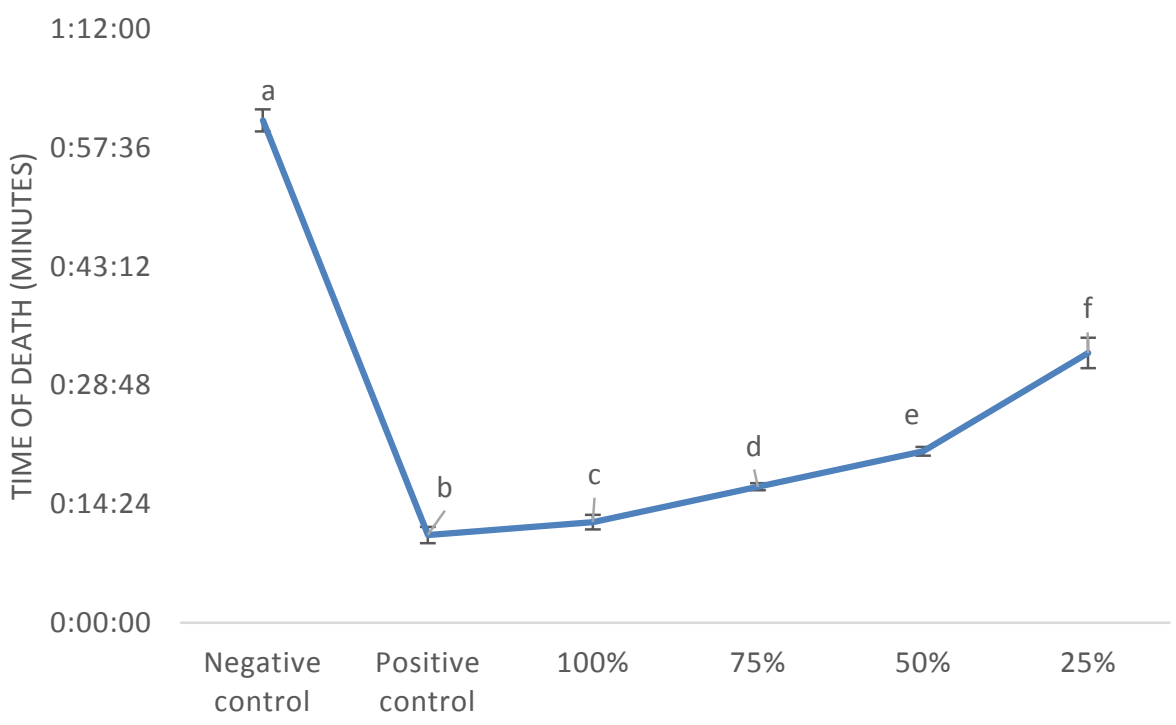

Figure 1. Results of measuring the time to death of head lice (Pediculus humanus capitis). Tukey's test results of the mean time to death of head lice (Pediculus humanus capitis) after treatment. Different letter showed significant level at Tukey test level of $5 \%$.

\subsection{Chemical analysis by GC-MS}

The essential oil of durian peel was analyzed using GC-MS to determine the content of the compounds contained. The components used were the GC variant CP-3800, MS Saturn 2200 detector, with an HP-5ms column 30Mx0.25MM IDx0.25 $\mu \mathrm{m}$. The results of the analysis show that there are 16 peaks with the 5 highest peaks presented in Figure 2.

The use of essential oils as a vegetable pediculoside formula is very potential because some essential oils are selective and have few side effects on non-target organisms so they are safe to use (Kassiri et al., 2014). In addition, the nature of essential oils which contain, for example, monoterpenoids, are very easy to extract and biodegrade, and are commonly used as fragrance and flavoring agents and preservatives in food and beverages, so they are very good and effective candidates as vegetable insecticides (Kassiri et al., 2014).

The highest bioactive compound component in durian peel essential oil is the 5(hydroxymethyl) furan-2-carbaldehyde compound with a percentage content of $50.18 \%$ (Table 2). This compound is a saccharide group or commonly called furfural, namely organic compounds derived from furan (Setyowati et al., 2014). Furfural is a dark yellow to brown liquid and has a strong aroma, presumably the distinctive and strong smell of durian comes from its furfural compounds (Illing, 2019). The 3,5- dihydroxy-2-methylpyran-4-one 
compound is a supporting compound for its activity as an antioxidant (Chandrasekar et al., 2015). Hexadecanoic acid (as. Palmitic) is a fatty acid that has anti-fungal properties (Nwaichi \& Osuoha, 2018). 1,5-naphthyridin-2-amine and [7- (benzoyloxyamino) -7-oxoheptanoyl] amino] benzoate compounds are alkaloids that function as antimicrobials (Chandrasekar et al., 2015). According to research (Arrizqiyani, 2018), bioactive compounds found in the durian peel essential oil test also have a repellant and insecticidal effect with a working mechanism by which essential oils enter through respiration, are eaten so that they enter the digestive tract and come into contact with the cuticles (Burgess, 2009). Data on the results of the time of death of lice and the number of lice were analyzed probit, the $\mathrm{LC}_{50}$ value (Lethal concentration) was obtained which was effective in causing the target lice to die of as much as $50 \%$ of the total observed tick population, namely $58.09 \%$ and obtained a $\mathrm{LT}_{50}$ (Lethal time) value, namely essential oil needed to kill the target lice as much as $50 \%$ of the population observed is 3 minutes. This is in line with other studies on the essential oil of kaffir lime peel which has an LC50 value of $40.5 \%$ to kill half of the observed population and an $\mathrm{LT}_{50}$ value of 2 minutes 55 seconds (Arrizqiyani, 2018). The essential oil that is naphthyridin- from durian peel has a mechanism of action in the form of stomach toxins which will damage the digestive tract of lice (Nwaichi \& Osuoha, 2018). This can be seen under a microscope, there is a decrease in digestive activity, until finally it does not move and dies.

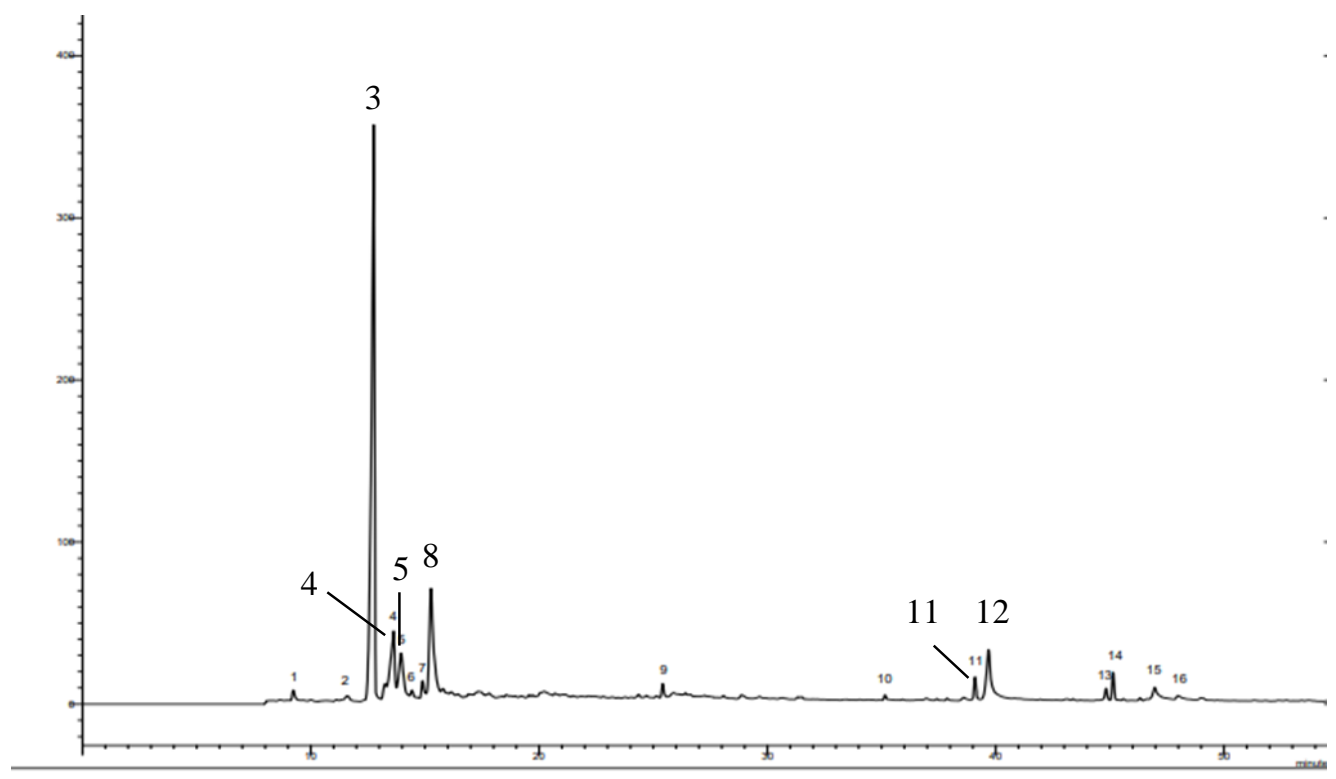

Figure 2. The five highest peaks of GC chromatogram of durian peel essential oil (Durio zibethinus) namely: 1,5-Naphthyridin-2-amine (Peak 3), 2-Furancarboxaldehyde, 5-(hydroxymethyl) (peak 8), Heptanediamide, N,N'-di- benzoyloxy (peak 4), 4HPyran-4-one, 3,5-dihydroxy-2-methyl (peak 5) and n-Hexadecanoic acid (peak 12).

The mechanism of active compounds in durian peel essential oil can kill lice because it has a desiccant toxic substance (Safar \& Nurhayati, 2010). The poison will make the body lose 
fluids continuously, so that the fleas die from drying out (Rukke et al., 2011). This is due to not covering it evaporation of water in the tick's body due to the melting of the fat / wax / cuticle layer on the tick's body (Burgess, 2009). The toxins enter through contact with the peel or enter through the exoskeleton (hard skeleton on the outside of the organism) into the body of the tick with the intermediary tarsus (toes) at resting on the surface containing residual material or insecticide residue (Madke \& Khopkar, 2012).

Table 2. The result component of durian peel essential oil (Durio zibethinus) with GC analysis.

\begin{tabular}{llcccc}
\hline No & \multicolumn{1}{c}{ Compound Name } & $\begin{array}{c}\text { Molecular } \\
\text { Mass }\end{array}$ & $\begin{array}{c}\text { Retention } \\
\text { Time }\end{array}$ & $\begin{array}{c}\text { \% } \\
\text { Content }\end{array}$ & $\begin{array}{c}\text { \% } \\
\text { Area }\end{array}$ \\
\hline 1 & $\begin{array}{l}\text { 1,5-naphthyridin-2-amine } \\
2\end{array}$ & 145 & 12,733 & $3,456,000$ & 50,18 \\
3 & $\begin{array}{l}\text { 2-Furancarboxaldehyde, 5- } \\
\text { (hydroxymethyl)- }\end{array}$ & 126 & 15,268 & $1,018,000$ & 14,78 \\
4 & $\begin{array}{l}\text { Heptanediamide, N,N'-di- } \\
\text { benzoyloxy- }\end{array}$ & 398 & 13,952 & 595,847 & 8,65 \\
4H-Pyran-4-one,3,5- & $\begin{array}{l}\text { dihydroxy-2- methylpyran } \\
5\end{array}$ & 142 & 13,952 & 478,293 & 6,94 \\
\hline
\end{tabular}

\section{Conclusion}

The conclusion from this research is that durian peel essential oil was able to kill head lice and the best concentration which similar to the result at positive control was at a concentration of $100 \%$.

\section{Acknowledgement}

The author thank to the Ministry of Research and Technology RI for the fund assistance through beginner Lecturer Research Grant Implementation year 2020.

\section{Conflict of Interest}

All author declared that there was no conflict of interest.

\section{References}

Amelia, L., Anwar, C., dan Wardiansyah. (2018). Association of Students Sociodemogrphic, Knowledge, Attitude and Practice with Pediculosis capitis in Pondok Pesantren Tahfidzil Qur'an Yayasan Tijarotal Lan Tabur Palembang, Indonesia. Bioscentia Medicina, 3(1), 51-63. www.bioscmed.com.

Arrizqiyani, T. (2018). Uji Efektivitas Formula Pedikulosida Berbahan Aktif Minyak Atsiri Terhadap Mortalitas Kutu Kepala (Pediculus humanus capitis De Geer) Secara In Vitro. The Journal of Muhammadiyah Medical Laboratory Technologist, 2(1), 1. https://doi.org/10.30651/jmlt.v2i1.1921.

Burgess, I. F. (2009). Current treatments for pediculosis capitis. Current Opinion in Infectious Diseases, 22(2), 131-136. https://doi.org/10.1097/QCO.0b013e328322a019.

Chandrasekar, T., Ram, M., Rao, K., Vijaya Kumar, R., Prabhu, K., Kumar, S. N., dan Divya, D. (2015). GC-MS analysis, antimicrobial, antioxidant activity of an Ayurvedic medicine, Nimbapatradi Choornam. Journal of Chemical and Pharmaceutical Research, 7(8), 124136. 
Coats, J. R., Karr, L. L., dan Drewes, C. D. (1991). Toxicity and Neurotoxic Effects of Monoterpenoids. 305-316. Iowa : Iwoa State University. https://doi.org/10.1021/bk1991-0449.ch020.

Departemen Kesehatan RI. (2000). Parameter Standar Umum Ekstrak Tumbuhan Obat. Jakarta : Departemen Kesehatan RI.

Fang, S. C., Hsu, C. L., dan Yen, G. C. (2008). Anti-inflammatory effects of phenolic compounds isolated from the fruits of Artocarpus heterophyllus. Journal of Agricultural and Food Chemistry, 56(12), 4463-4468. https://doi.org/10.1021/jf800444g.

Illing, I. (2019). Identifikasi Senyawa Steroid Dari Pangsa Kulit Durian (Durio zibethinus). Cokroaminoto Journal of Chemical Science, 1(1), 3-5. https://science.ejournal.my.id/cjcs/article/view/10.

Karimah, A., Hidayah, R. M. N., dan Dahlan, A. (2016). Prevalence and Predisposing Factors of Pediculosis Capitis on Elementary School Students at Jatinangor. Althea Medical Journal, 3(2), 254-258. https://doi.org/10.15850/amj.v3n2.787.

Kassiri, H., Feizhaddad, M.-H., dan Abdehpanah, M. (2014). Morbidity, surveillance and epidemiology of scorpion sting, cutaneous leishmaniasis and pediculosis capitis in Bandar-mahshahr County, Southwestern Iran. Journal of Acute Disease, 3(3), 194-200. https://doi.org/10.1016/s2221-6189(14)60043-3.

Irianto, K. (2013). Parasitologi medis (Medical parasitogy). Bandung : Alfabeta.

Madke, B., dan Khopkar, U. (2012). Pediculosis capitis: An update. Indian Journal of Dermatology, Venereology and Leprology, 78(4), 429-438. https://doi.org/10.4103/0378-6323.98072.

Mulyani, T. Y. W., Widodo, S., dan Selviani, L. (2019). Fraksi Etanol Ekstrak Kulit Durian (Durio Zibethinus L.) Sebagai Antifungi Terhadap Trichophyton mentagrophytes dan Candida albicans. JFL: Jurnal Farmasi Lampung, 8(1), 28-38. https://doi.org/10.37090/jfl.v8i1.84.

Nwaichi, E. O., dan Osuoha, J. O. (2018). Essential Oil and Fatty Acid Constituents of Buccholzia coriacea (Wonderful Kola) Seeds Harvested in Nigeria. Biochemistry \& Physiology: Open Access, 07(02). https://doi.org/10.4172/2168-9652.1000233.

Orole, O. (2016). GC-MS Evaluation, Phytochemical and Antinutritional Screening of Ganoderma lucidum. Journal of Advances in Biology \& Biotechnology, 5(4), 1-10. https://doi.org/10.9734/jabb/2016/24261.

Rukke, B. A., Birkemoe, T., Soleng, A., Lindstedt, H. H., dan Ottesen, P. (2011). Head lice prevalence among households in Norway: Importance of spatial variables and individual and household characteristics. Parasitology, 138(10), 1296-1304. https://doi.org/10.1017/S0031182011001004.

Safar, R. H., dan Nurhayati, N. (2010). Parasitologi kedokteran : protozoologi, helmintologi, entomologi (Nunung Nurhayati. (ed.)). Bandung : Bandung Yrama Widya.

Setyowati, W. A. E., Ariani, S. R. D., Ashadi, Putri, R. C., dan Mulyani, B. (2014). Skrining Fitokimia dan Identifikasi Komponen Utama Ekstrak Metanol Kulit Durian ( Durio zibethinus Murr .) Varietas Petruk. Seminar Nasional Kimia dan Pendidikan Kimia VI, 271-280.

Tohit, N. F. M., Rampal, L., dan Mun-Sann, L. (2017). Prevalence and predictors of pediculosis capitis among primary school children in Hulu Langat, Selangor. Medical Journal of Malaysia, 72(1), 12-17.

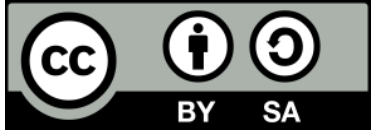

(C) 2021 by the authors. Submitted for possible open access publication under the terms and conditions of the Creative Commons Attribution-ShareAlike 4.0 International (CC BY-SA 4.0) license (https://creativecommons.org/licenses/by-sa/4.0/). 